ORIGINALNI

ČLANAK

\title{
Stavovi lokalnog
}

stanovništva prema uticaju turizma na Paliću

\author{
Attitudes of the locals towards tourism \\ impact on Palić
}

\author{
Srđan Milošević, Fakultet za sport i turizam, Novi Sad \\ Dušan Perić, Fakultet za sport i turizam, Novi Sad \\ Miljana Vujinović
}

SAŽETAK U ovom radu se razmatraju stavovi lokalnog stanovništva prema uticaju turizma na turističku destinaciju Palić. Analiziranjem uloge rezidenata u procesu razvoja turizma, ukazuje se na aktuelno stanje, moguće uticaje, kao i na potencijalno unapređenja turizma. Cilj ovog rada se

Ključne reči: turistička destinacija,

lokalno stanovništvo, uticaj turizma,

Palić

\section{ABSTRACT}

Keywords: Tourist destination, Local population,

The impact of tourism,

Palić ogleda u utvrđivanju uticaja turizma na destinaciju Palić posmatran kroz stavove, uključenost i doprinos lokalnog stanovništva. Na uzorku od 100 odraslih osoba sprovedena je anketa sa 18 pitanja koja su preuzeta iz prethodnih sličnih istraživanja. Pomoću Kronbahove alfe utvrđena je dobra unutrašnja pouzdanost upitnika. Utvrđeno je da lokalno stanovništvo Palića generalno visoko ocenjuje uticaj turizma i prepoznaje njegov pozitivan uticaj na lokalni razvoj. Žene su bile strože u proceni uticaja turizma, dok se ocene ispitanika različite starosti nisu značajno razlikovale. Značaj turizma za lokalni razvoj više prepoznaju oni koji su u njemu angažovani. Realni uticaj sva tri faktora (pol, starost i angažovanost u turizmu) međutim, bio je mali.

This paper discusses the attitudes of the local population towards the impact of tourism on the tourist destination Palić. By researching the role and the importance of the local population in the process of tourism development, what is presented is the current situation, positive and negative influences as well as the possibilities of improving tourism. The aim of this paper is to determine the impact of tourism on destination Palic observed through the attitudes, involvement, and the contribution of the local population. A sample of 100 adults was surveyed with 18 questions taken from previous similar surveys. The good internal reliability of the questionnaire was determined by using Cronbach's alpha. It was found that the local population of Palic generally highly evaluates the impact of tourism and recognizes its positive impact on the local development. Women were stricter in assessing the impact of tourism, while the assessment of respondents of different ages did not differ significantly. The importance of tourism for the local development is more recognized by those who are engaged in it. However, the real impact of all three factors (gender, age, and engagement in tourism) was small. 
Milošević, S., Perić, D., Vujinović, M. - Stavovi lokalnog stanovništva prema uticaju turizma na Paliću 2020. Fakultet za sport i turizam, Novi Sad, Tims.Acta 14, 41-51

\section{Uvod}

Turizam može ostvariti pozitivne i negativne uticaje, a konačna vrednost teško se može utvrditi jer često sadrži obe vrste uticaja. Potpora zajednice u procesu razvoja turizma potrebna je u dostizanju principa održivosti destinacije, pa zato ne čudi što je lokalno stanovništvo ključni faktor u procesu razvoja turizma. Percepcija lokalnog stanovništva o stvarnim uticajima turizma na lokalnu zajednicu, odnosno stvarna promena $\mathrm{u}$ pogledu kvaliteta života lokalnog stanovništva, odrediće stepen prihvatanja turizma i turističkog sadržaja kao načina privređivanja. Kako navodi Denda (2014), svako podneblje, sa svojim konkretnim karakteristikama, pruža mogućnost za odvijanje brojnih, kako prirodnih, tako i antropogenih procesa među koje spada i turizam kao delatnost. Li (Lee, 2013) smatra da turizam kao privredna grana ima veoma veliki uticaj na lokalnu zajednicu, a isto tako i na okruženje. Razvoj turizma donosi brojne pozitivne ekonomske efekte (kao što su mogućnost zapošljavanja, poboljšanje infrastrukture i slično), ali isto tako može proizvesti i brojne negativne posledice, kako po društvo, tako i po životnu sredinu (kriminal, saobraćajne gužve, veći porez na imovinu, itd). Uključivanjem lokalnog stanovništva u proces definisanja potreba potencijala destinacije stvara se ponuda koja uvažava potrebe lokalnog područja. Kao rezultat takvog pristupa postiže se održivost upravljanja turističkim sadržajem destinacije.

\section{Studija slučaja}

Palić već godinama predstavlja jednu od najposećenijih lokacija u Srbiji, pre svega, zbog svoje uređenosti, lepote i raznovrsnih mogućnosti za odmor i rekreaciju. Na obali jezera nalaze se tri kupališta: peščana plaža, kupalište kod Ženskog štranda i kupalište kod Muškog štranda. Na Paliću se nalazi 62 smeštajna objekta (hotel, hotel garni, privatni smeštaj, prenoćište i kamping odmorište) sa 525 soba i 1160 ležajeva. Smeštajna struktura Palića, iako pripada kategoriji hotela i garni hotela sa $4 *$, zbog ograničenosti usluga koje pruža, ne odgovara zahtevima internacionalnog tržišta. Kako se može videti na zvaničnom sajtu Turističke organizacije grada Subotica (visitsubotica.rs), svi hoteli nude i dodatne sadržaje za svoje goste koji upotpunjuju njihov boravak na ovoj destinaciji, ali ne predstavljaju primarni razlog boravka i dolaska gostiju. Za razvoj turizma na Paliću ključno je ulaganje u infrastrukturu. Razvijena saobraćajna infrastruktura predstavlja ključni faktor za razvoj turizma na destinaciji. Palić je udaljen $8 \mathrm{~km}$ od Subotice, $18 \mathrm{~km}$ od graničnog prelaza Kelebija i 20 km od graničnog prelaza Horgoš. Najavljena rekonstrukcija pruga imaće, takođe, veliki uticaj na turizam na Paliću. U prethodnom periodu značajna sredstva su uložena u podizanje kvaliteta infrastrukture, kroz aktivnosti kao što su renoviranje, restauracija, izgradnja i adaptacija.

Podaci Turističke organizacije grada Subotice za 2018 . godinu (Turistička organizacije grada Subotice, 2019) pokazuju da je tokom prethodne godine grad Suboticu i Palić posetilo 150000 turista, domaćih i stranih, od čega je jedna trećina (50 313) stranih turista. U turističkoj organizaciji ističu da se beleže pozitivni trendovi: broj turista u 2018. godini porastao je za $7 \%$, dok je broj stranih turista viši za $9 \%$. Dominantno su prisutni domaći turisti, dok se od 2017. godine beleži značajan porast broja stranih turista, među kojima su najbrojniji posetioci iz Kine (ovome je u velikoj meri doprineo bezvizni režim koji Srbija ima sa Kinom). Posetioci iz Poljske i Mađarske ostvaruju oko 25\% noćenja od ukupnog broja stranih dolazaka, a pored njih, zabeleženi su i posetioci iz Nemačke, Slovenije, Bosne i Hercegovine, Makedonije, Rumunije, Hrvatske ali i mnogi drugi. Prosečno zadržavanje gostiju na ovoj destinaciji je veoma kratko i iznosi u proseku samo dva dana. Najveća poseta na Paliću beleži se u letnjim mesecima maju, junu, julu i avgustu, ali zbog velikog broja manifestacija, i u septembru je zabeležen značajan broj posetilaca.

\section{Uticaj turizma na destinaciju}

Kada je reč o turističkoj destinaciji treba reći da ona, kao i sam pojam turizam, ima kompleksno značenje, tako da zavisi od velikog broja faktora. Ubavić (2015, str. 82) ističe da je "pojam destinacije široko prihvaćen“, kao i da "postoje brojne razlike u pogledu značenja suštine ovog pojma u turizmu“. Turistička destinacija podrazumeva širi prostor koji privlači veliki broj turista i svoj turistički identitet gradi na koncepciji kumulativnih atrakcija koje omogućavaju doživljaj (Stefanović \& Gligorijević, 2010). Matison i Vol (Mathieson \& Wall, 1990) pod turističkom destinacijom podrazumevaju prostor koji ima karakteristike koje su poznate velikom broju potencijalnih posetilaca, međutim, ovakav stav je prevaziđen upravo zbog činjenice da savremene destinacije u prvi plan svojih aktivnosti ističu upravo život običnog lokalca. Savremeno shvatanje koncepta turističke destinacije podrazumeva tržišno prilagođenu 
Milošević, S., Perić, D., Vujinović, M. - Stavovi lokalnog stanovništva prema uticaju turizma na Paliću 2020. Fakultet za sport i turizam, Novi Sad, Tims.Acta 14, 41-51

prostornu oblast sa optimalno usklađenim sistemom elemenata i funkcija, gde se teži dugoročnom postizanju dobrih turističkih rezultata (Jovičić, 2010). Gotovo sve postojeće definicije turističke destinacije ukazuju na to da ona predstavlja prostornu celinu koja ima privlačnu snagu (atraktivnost) i opremljenost za dolazak i boravak turista. Većina turista ima svoje odredište - mesto gde putuju. Svako mesto ima sopstvene karakteristike koje su rezultat prirodnih fizičkih sila i delovanja čoveka. Primarni resurs destinacije su atraktivni sadržaji koji imaju dve funkcije - privući gosta i ispuniti njegova očekivanja (Stefanović, 2010). Uprkos činjenici da je teško proizvesti kompletnu i jedinstvenu definiciju turističke destinacije, zahvaljujući raznovrsnosti njenih elemenata, Kandela i Finjini (Candela \& Figini, 2012) tvrde da je ipak moguće navesti neke zajedničke karakteristike svih destinacija: (1) svaka destinacije predstavlja čvrst spoj i sve komponente iz kojih se ona sastoji moraju deliti jednake kvalitativne osobine i njima se mora efikasno upravljati; (2) sve destinacije imaju vrednost: da bi lokacija postala turistička destinacija mora se početi percipirati kao zanimljiva i vredna posete, što znači da se mora adaptirati prema potrebama i željama turista, i to u kvantitativnom i kvalitativnom smislu; (3) sve destinacije su nedeljive od turističke potrošnje - značaj turizma se ogleda upravo u tome da se proizvod/usluga konzumira tamo gde se i proizvodi, turistički proizvod je kratkotrajan i prolazan, ne može se transportovati zbog čega destinacije često pate zbog tzv. turističkog pritiska, što se najpre odnosi na problem sezone destinacije, kada se $u$ isto vreme mnogo turista nadmeće za iste resurse; (4) postojeće strukture i infrastrukture na destinaciji ne služe samo turistima već i ostalim ljudima, najviše rezidentima, odnosno lokalnom stanovništvu destinacije. Iz tog razloga, turizam ponekad na destinaciji može uzrokovati konflikte i nadmetanje između turista i lokalne zajednice (Candela \& Figini, 2012). Međutim, „ukoliko se uspešno planira njegov razvoj, to može doprineti značajnom stvaranju prihoda i obezbediti zaposlenje značajnom delu populacije" (Milošević, 2017, str. 32).

Danas se najčešće raspravlja o pozitivnim i negativnim uticajima razvoja turizma. lako se dugo godina smatralo da je turizam fenomen bez negativnih uticaja na destinaciju, danas uz sve zastupljeniji avio-saobraćaj i povećanje turističkog prometa, turizam donosi i negativne posledice. Turistička industrija ima direktan uticaj na ekonomiju jedne zemlje, ali ima veoma značajan i socio-kulturološki uticaj (Milošević, 2016). Stojanović (2006) ističe da svaka destinacija na kojoj se razvija turizam trpi određene pritiske u ekonomskoj, ekološkoj i socio-kulturnoj oblasti. Promene koje izazivaju ovi pritisci mogu biti pozitivni i negativni i zavise od velikog broja činilaca, a najčešće od lokalnih činilaca.

Tabela 1. Uticaji turizma

\begin{tabular}{|c|c|c|}
\hline Uticaj & Pozitivni & Negativni \\
\hline Socio-kulturni & $\begin{array}{l}\text { Očuvanje i unapređenje regionalne kulturne } \\
\text { baštine } \\
\text { Učešće lokalnog stanovništva u aktivnostima } \\
\text { i dešavanjima }\end{array}$ & $\begin{array}{l}\text { Promene u strukturi stanovništva } \\
\text { Isključenost lokalnog stanovništva iz dešavanja } \\
\text { Viša stopa kriminala } \\
\text { Promena prirode događaja i aktivnosti radi zadovoljenja } \\
\text { turističkih potreba }\end{array}$ \\
\hline
\end{tabular}

Izvor: (Hall \& Page, 2002, U: Stojanović, 2006)

Veliki broj turističkih destinacija, bilo da su lokalnog, regionalnog ili nacionalnog karaktera, suočile su se sa značajnim pritiskom na prirodne i kulturne resurse, ali i na socio-ekonomsko okruženje, što je uzrokovano intenzivnim rastom nekontrolisanog turizma. Ovakav razvoj turizma ogleda se u negativnim uticajima, narušava životnu sredinu i kulturu lokalne zajednice, a samim tim uništava i osnovu na kojoj se zasniva razvoj, pa autor Jegdić (2011) dalje ističe i da težnja ka sveukupnom održivom razvoju u kojem će turizam imati značajnu ulogu, zahteva da se uloži dodatni napor. 
Milošević, S., Perić, D., Vujinović, M. - Stavovi lokalnog stanovništva prema uticaju turizma na Paliću 2020. Fakultet za sport i turizam, Novi Sad, Tims.Acta 14, 41-51

Lokalno stanovništvo na turističkoj destinaciji

Turizam ne samo da menja okolinu u kojoj se razvija, već dovodi i do značajnih promena kod lokalnog stanovništva (Tepavčević, Blešić, Bradić, \& Ivkov, 2019). Lokalno stanovništvo predstavlja veoma važan faktor u razvoju turizma na destinaciji. Rudan (2012) ističe da je prilikom definisanja vizije veoma važno uvažiti entuzijazam lokalnog stanovništva, jer se tako stvara ponuda koja razume potrebe lokalnog područja. Takođe, mora se istaći da stanovništvo kroz razvoj turizma ostvaruje i materijalnu korist. Boranić-Živoder, Tomljenović i Čorak (2011) navode da nivo do kojeg je stanovništvo spremno da toleriše negativne efekte zavisi od njihove uključenosti u turističku realizaciju i od uticaja turističkog prometa na njihov svakodnevni život. Long, Perdu i Alen (Long, Perdue, \& Alen, 1990) razvili su model koji se bavi ispitivanjem odnosa između percepcije rezidenata prema turističkom uticaju i njihove podrške turizmu. Došlo se do saznanja da rezidenti, u najvećoj meri, podržavaju razvoj turizma, kao i određene razvojne politike na destinaciji, ukoliko imaju lične koristi od istog. Ovaj model pretpostavlja da će podrška restriktivnoj politici, takse i posebni turistički porezi, negativno uticati na turistički razvoj. Rezultati su pokazali da je potrebno uticati na percepciju javnosti o pozitivnim i negativnim uticajima turizma jer se usmerenje na ekonomske koristi pokazalo kao nedovoljno. Gredičak (2009) ističe da lokalno stanovništvo tretira objekte kulturne baštine kao nešto iz susednog dvorišta, jer su to prethodne generacije izgradile, te je u tom smislu prisutan određeni ponos na sopstvenu kulturno-istorijsku baštinu. Tosun (Tosun, 2000) smatra da ako su ciljevi turizma postizanje održivog razvoja, ciljne mere moraju biti pažljivo propisane kako bi lokalno stanovništvo dobilo mogućnost da iskoristi prednosti ukazanih mogućnosti koje pruža razvoj turizma. Nasuprot negativnim efektima koje turizam ima po životnu sredinu, razvoj održivog i odgovornog turizma donosi mnogobrojne pozitivne efekte (Božić \& Milošević, 2019, str. 54).

Dakle, ukoliko se ne narušava kvalitet života u turističkoj destinaciji i stanovništvo će biti zadovoljno turističkim razvojem. Da bi se ostvario pozitivan društveni uticaj turizma kod stanovništva, potrebno je jačati ljudske resurse u oblasti turizma, što može uticati na sve veće prihvatanje ovog sektora kroz unapređenje ponude i popularizaciju poslova.

\section{Metodologija}

U radu su ispitivani stavovi i mišljenja stanovništva destinacije Palić o razvoju turizma i njegovim pozitivnim i negativnim uticajima na lokalnu zajednicu i životni standard. Kao instrument prikupljanja podataka korišćena je anketa koja je elektronskim putem distribuirana lokalnom stanovništvu turističke destinacije Palić, na uzorku od 100 ispitanika. Prvi deo ankete odnosio se na socio-demografske karakteristike (pol, starost, obrazovanje), dok se drugi deo sastojao od zavisnih varijabli koje su ocenjivane primenom Likertove skale. Ovo istraživanje predstavlja studiju empirijskog karaktera i sprovedeno je u avgustu i septembru mesecu 2019. godine. Rezultati dobijeni ovim istraživanjem mogu dovesti do novih saznanja i predloga mera poboljšanja, razvoja i unapređenja turističke ponude na ovoj destinaciji, ali i do stvaranja uslova za veći podsticaj, osnaživanje i uključenost lokalnog stanovništva u proces razvoja Palića, čime bi se ujedno poboljšao kvalitet života svih u zajednici.

\section{Uzorak}

Uzorkom je obuhvaćeno 100 ispitanika (46 muškaraca i 54 žene) među kojima najviše mlađih i sredovečnih osoba (48 ispitanika mlađih od 40 godina, 42 ispitanika starosti između 40 i 59 godina i 10 ispitanika starijih od 60 godina). Broj profesionalno angažovanih u turizmu i onih koji sa njim nisu ekonomski povezani je ujednačen (49 ispitanika radi u turizmu).

\section{Instrument}

Podaci su prikupljeni pomoću adaptiranog instrumenta TIAS skale (Tourism Impact Attitude Scale) čije su metrijske karakteristike potvrđene $u$ prethodnim istraživanjima (Lankford \& Howard, 1994). Za ovu studiju je odabrano 18 tvrdnji. Ispitanici su prihvatanje/ odbacivanje iskazivali izborom odgovarajuće numeričke vrednosti na petostepenoj skali Likertovog tipa. Najveća skalarna vrednost (5) znači potpuno slaganje, a najmanja (1) potpuno neslaganje sa nekom od tvrdnji. Da bi se očuvala logika skale u kojoj najviša numerička vrednost odgovara najpozitivnijem, a najniža najnegativnijem stavu prema određenoj tvrdnji, u ajtemima sa negativnim iskazima izvršena je inverzija skalarnih vrednosti (ocena 5 konvertovana je u 1 , ocena 4 u 2, ocena 2 u 4 i ocena 1 u 
Milošević, S., Perić, D., Vujinović, M. - Stavovi lokalnog stanovništva prema uticaju turizma na Paliću 2020. Fakultet za sport i turizam, Novi Sad, Tims.Acta 14, 41-51

5). Ovako konvertovane skalarne vrednosti korišćene su za statističku analizu podataka.

Pouzdanost (unutrašnja saglasnost) upitnika kojim su prikupljeni podaci ocenjena je standardnim statističkim postupkom (Scale Reliability Analysis) zasnovanom na tumačenju Kronbahove alfe (Cronbach's Alpha). Dobijeni rezultati (Tabela 2) pokazuju da skala ima dobru unutrašnju saglasnost budući da je Kronbahova alfa veća od preporučene teorijske vrednosti 0,7 (De Vellis, 2003). Time je potvrđen dobar izbor tvrdnji (iskaza) za inicijalni upitnik.

Tabela 2. Rezultati analize pouzdanosti (unutrašnje saglasnosti) inicijalnog upitnika

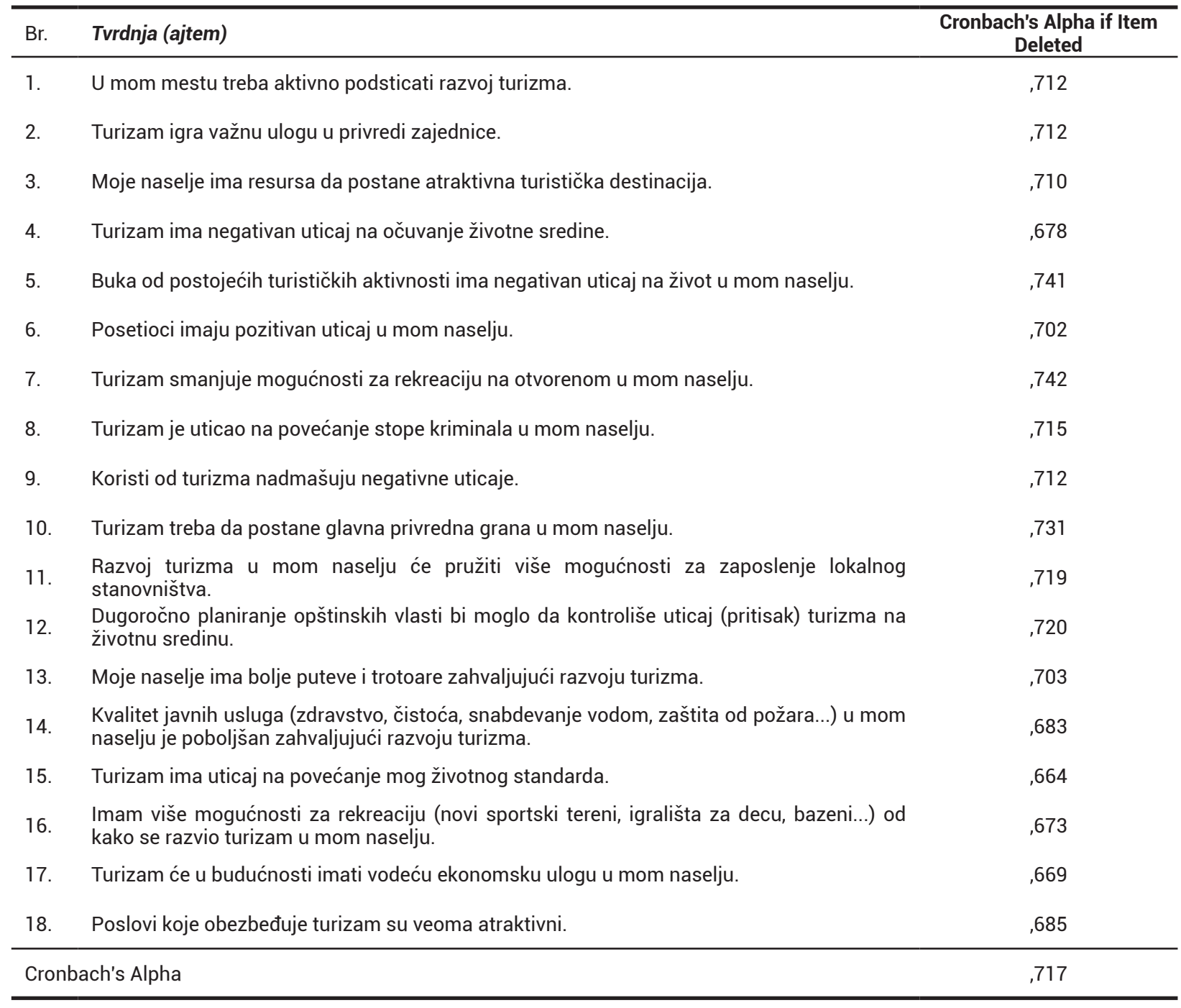

\section{Statistička obrada podataka}

Za proveru faktorske validnosti i utvrđivanje latentne strukture 18-ajtemskog upitnika kojim su prikupljeni podaci, primenjena je Faktorska analiza po modelu glavnih komponenti (Principal Components Analysis - PCA), sa direktnom kosom rotacijom i Kajzerovom normalizacijom (Direct Oblimin method of rotation with Kaiser Normalization). Iz podataka o ajtemima koji su formirali generalni faktor izračunati su skalarni prosek, odnosno aritmetička sredina (Mean) i standardna devijacija (SD). Uticaj pola, starosti i angažovanja ispitanika u turizmu na razlike između skalarnih proseka testiran je višefaktorskom analizom varijanse različitih grupa. S obzirom na to da je Leveneov test (Levene's Test of Equality of Error Variances) pokazao da varijansa zavisne promenljive nije jednaka u svim grupama $\left(F_{[11}\right.$, $\left.{ }_{88]}=2,096 ; p=0,029\right)$, zaključivanja su sprovedena sa nivoom značajnosti $0,01(p \leq, 01)$ što je stroži kriterijum od uobičajenih 0,05 (Tabachnick \& Fidell, 2007). Podaci su obrađeni pomoću aplikacionog statističkog programa SPSS (Portable IBM SPSS v.21 application). 


\section{Rezultati istraživanja}

\section{Validnost skale}

Validnost 18-ajtemskog upitnika ocenjena je pomoću faktorske analize glavnih komponenti (PCA). Tome je prethodila procena prikladnosti podataka za faktorsku analizu. Pregledom korelacione matrice evidentirano je mnogo koeficijenata vrednosti 0,3 i više. KMO (KaiserMeyer-Olkin Measure of Sampling Adequacy) iznosi 0,63 što je više od teorijskog limita 0,6 kojeg je preporučio Kajzer (Kaiser, 1970; 1974). Bartletov test (Bartlett's test of sphericity, 1954) takođe je ukazao na statističku signifikantnost dobijenog faktorskog modela. Na osnovu toga zaključeno je da inicijalna korelaciona matrica ima dobru faktorabilnost.

Međutim, analiza glavnih komponenti, dobijenih Oblimin rotacijom, otkrila je čak 6 komponenti sa karakterističnim korenom (Eiegenvalue) preko jedan. Nakon kose rotacije ovih 6 komponenti dobijena je matrica sklopa (Paterrn Matrix) u kojoj je veliki broj varijabli bio značajno povezan sa više od jednog faktora, a bilo je i veoma mnogo koeficijenata korelacije manjih od 0,3. Ovi podaci ukazali su na neodrživost inicijalne matrice, što potkrepljuje i dijagram prevoja (Scree Plot) u kojem se tačka loma nalazi već iza druge komponente (Slika 1). Na osnovu Katelovog kriterijuma (Kattel, 1966) odlučeno je da se zadrži samo jedna komponenta, što su podržali i rezultati paralelne analize čije karakteristične vrednosti premašuju odgovarajući statistički prag (Watkins, 2000) dobijen pomoću jednako velike matrice slučajnih brojeva (18 varijabli x 100 ispitanika).

Ponavljanjem PCA sa jednokomponentnim modelom dobijeno je rešenje koje objašnjava svega 24,791\% varijanse, što je statistički neprihvatljivo. Ovako nizak procenat objašnjenog varijabiliteta najverovatnije je posledica velikog broja varijabli (čak 8) sa komunalitetima manjim od teorijskog limita 0,3. Ovih 8 varijabli (broj 5, 6, 7, 8, 9, 10, 11 i 12) eliminisano je iz sistema, a jednokomponentni model PCA ponovljen sa 10 preostalih varijabli. Ponovljeni faktorski postupak doneo je značajno stabilnije i interpretabilnije rešenje (Tabela 3). Jedina komponenta novog sistema (od koje je formiran generalni faktor) imala je karakterističan koren (Eigenvalue) 4,874 i objašnjavala zadovoljavajućih $49 \%$ ukupnog varijabiliteta.

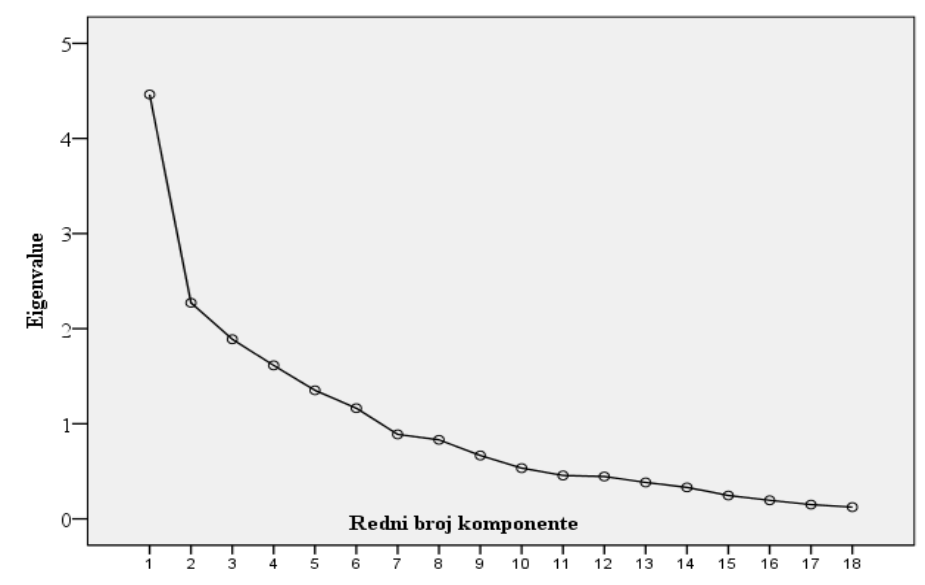

Slika 1. Inicijalni dijagram prevoja (Scree Plot) dobijen za 18 ajtema upitnika o turizmu

Korigovanjem inicijalne matrice dobijen je stabilan jednokomponentni model u kojem sve varijable imaju komunalitet veći od 0,3 i značajanu korelacionu vezu sa glavnom komponentom (Tabela 3). Najveći uticaj na formiranje generalnog faktora imale su varijable broj 17 , 18 i 16, a zatim varijable broj 15, 14 i 2 . Glavna komponenta najmanje je saturiran varijablom broj 4 , jedinom koja sadrži negativan iskaz. Sistem varijabli okupljenih oko generalnog faktora je veoma konzistentan na šta ukazuje visoka Kronbahova alfa (Cronbach's Alfa $=0,808$ ) koja je premašila vrednost dobijenu za inicijalnu matricu. Sve to pokazuje da konačni upitnik od 10 tvrdnji može da se koristi u narednim istraživanjima kao jedinstvena kratka skala.

Analiza sadržaja 10 tvrdnji novoformiranog upitnika (Tabela 4) pokazuje da su ekonomski aspekti turizma presudni za formiranje pozitivnog odnosa ispitanika prema turizmu. U upitniku je zadržana samo jedna negativna tvrdnja i odnosi se na narušavanje/očuvanje životne sredine. Sadržaji tvrdnji otkrivaju da ispitanici najlakše prepoznaju lako vidljive i ekonomski opipljive društvene elemente koji se mogu dovesti u vezu sa razvojem turizma. 
Milošević, S., Perić, D., Vujinović, M. - Stavovi lokalnog stanovništva prema uticaju turizma na Paliću 2020. Fakultet za sport i turizam, Novi Sad, Tims.Acta 14, 41-51

\begin{tabular}{ccc}
\hline & Tabela 3. Finalna faktorska matrica & \\
\hline Varijabla & Komponenta (faktor) & Komunaliteti \\
\hline T.17 &, 788 &, 621 \\
T.16 &, 783 &, 612 \\
T.18 &, 728 &, 530 \\
T.15 &, 692 &, 479 \\
T.14 &, 635 &, 404 \\
T.2 &, 608 &, 370 \\
T.3 &, 561 &, 324 \\
T.13 &, 560 &, 323 \\
T.1 &, 556 &, 319 \\
T.4 &, 472 &, 303 \\
\hline
\end{tabular}

Tabela 4. Finalni upitnik sa 10 tvrdnji visoke validnosti i pouzdanosti

\begin{tabular}{clc}
\hline Br. & \multicolumn{1}{c}{ Tvrdnja (iskaz) } & Koeficijenti \\
\hline 1. & Turizam će u budućnosti imati vodeću ekonomsku ulogu u mom naselju. &, 788 \\
2. & Sa razvojem turizma raste mogućnosti za rekreaciju (grade se nova igrališta, bazeni...). &, 783 \\
3. & Poslovi koje obezbeđuje turizam su veoma atraktivni. &, 728 \\
4. & Turizam ima uticaj na povećanje mog životnog standarda. &, 692 \\
5. & Sa razvojem turizma unapređuju se sve javne usluge (zdravstvo, čistoća, snabdevanje...). &, 635 \\
6. & Turizam igra važnu ulogu u privredi zajednice. &, 608 \\
7. & Moje naselje ima resursa da postane atraktivna turistička destinacija. &, 561 \\
8. & Moje naselje ima bolje puteve i trotoare zahvaljujući razvoju turizma. &, 560 \\
9. & Za napredak društva je važno aktivno podsticati razvoj turizma. &, 556 \\
10. & Turizam ima negativan uticaj na očuvanje životne sredine. &, 472 \\
\hline
\end{tabular}

Cronbach's Alpha $=, 808$

\section{Skalarne vrednosti}

Iz podataka koji se odnose na 10 varijabli zadržanih u finalnoj faktorskoj matrici, izračunati su osnovni deskriptivni parametri (Mean i SD). Prosečne skalarne vrednosti iskazane su za svaki specifični subuzorak formiran ukrštanjem tri faktora: pola, starosti i angažmana u turizmu. Analizom varijanse utvrđeno je da se proseci ispitanika različite starosti nisu značajno razlikovali $(F=$ $1,237 ; p=0,295)$ zbog čega su ovde detaljno prikazani i analizirani samo statistički podaci koji se odnose na uticaj pola i (ne)angažovanost ispitanika u turizmu (Tabela 5).

Najveći broj skalarnih proseka je veći od 4 , a svi su preko 3,6 što pokazuje da većina anketiranih stanovnika Palića prepoznaje pozitivan uticaj turizma na lokalni razvoj i daje mu značajnu prednost nad potencijalnim negativnim efektima. 
Milošević, S., Perić, D., Vujinović, M. - Stavovi lokalnog stanovništva prema uticaju turizma na Paliću 2020. Fakultet za sport i turizam, Novi Sad, Tims.Acta 14, 41-51

Tabela 5. Skalarni proseci različitih grupa ispitanika

\begin{tabular}{|c|c|c|c|c|}
\hline Angažman & Pol & Mean & SD & $\mathbf{N}$ \\
\hline Rade u & Muškarci & 4,355 & ,4925 & 20 \\
\hline \multirow[t]{2}{*}{ turizmu } & Žene & 4,041 & 7008 & 29 \\
\hline & Total & 4,169 & 6378 & 49 \\
\hline Ne rade & Muškarci & 4,081 & ,4128 & 26 \\
\hline \multirow[t]{2}{*}{ u turizmu } & Žene & 3,684 & 6087 & 25 \\
\hline & Total & 3,886 & ,5506 & 51 \\
\hline \multirow[t]{3}{*}{ Total } & Muškarci & 4,200 & ,4648 & 46 \\
\hline & Žene & 3,876 & 6779 & 54 \\
\hline & Total & 4,025 & 6088 & 100 \\
\hline
\end{tabular}

Rezultati faktorske analize varijanse različitih grupa (Tabela 6) pokazuju da interakcija dve nezavisne varijable (pola i angažovanosti u turizmu) nije bila statistički značajna, dok je njihov odvojeni uticaj prouzrokovao signifikantne razlike između skalarnih proseka muškaraca i žena, kao i onih koji rade i ne rade u turizmu. Parcijalni Eta kvadrati obe nezavisne varijable, međutim, manji su od teorijske vrednosti 0,138 i prema Koenovom kriterijumu (Cohen, 1988) njihov uticaj se može klasifikovati kao srednje jak. Prema tome, iako statistički značajna, stvarna razlika između aritmetičkih sredina je mala.

Tabela 6. Mere uticaja nezavisnih varijabli na zavisnu varijablu

\begin{tabular}{cccc}
\hline Uticaj & F & Sig. & Partial Eta Squared \\
\hline Interakcija faktora & 0,129 &, 720 &, 001 \\
Pol & 9,435 &, 003 &, 072 \\
\hline
\end{tabular}

\section{Diskusija}

Cilj istraživanja u ovom radu je utvrđivanje uticaja razvoja turizma na destinaciji Palić koji utiče na svakodnevni život lokalnog stanovništva. Podaci su prikupljeni primenom modifikovanog upitnika sastavljenog pomoću standardizovane TIAS skale za merenje uticaja turizma na stavove lokalnog stanovništva. Autori skale (Lankford \& Howard, 1994) istraživanjem dolaze do ajtema grupisanih u dva faktora: (1) briga za lokalni turistički razvoj i (2) korist za pojedince i lokalnu sredinu. Prvi faktor sadržao je 18, a drugi 9 ajtema. U istraživanju koje je sproveo Vusnam (Woosnam, 2012), isto je dobijena dvofaktorska struktura. Autor je prvi faktor imenovao podrška turističkom razvoju, a drugi doprinos zajednici. Istraživanjem koje su sproveli Vang i saradnici (Wang, Pfister, \& Morais, 2006), takođe je dobijena dvofaktorska struktura koja se pokazala kao veoma korisna za merenje stavova lokalnog stanovništva o uticaju turizma.

Kako navodi i Milošević (2016), pored gore navedenih istraživanja, u literaturi se takođe mogu naći istraživanja sa istim ciljem, u kojima je dobijeno i više od dva faktora. Merenje faktora kroz pozitivan i negativan uticaj na lokalnu zajednicu je zajedničko svim ovim istraživanjima. Autori Anderek i Vogt (Andereck \& Vogt, 2000) istraživanjem koje su sproveli u sedam lokalnih zajednica u Sjedinjenim Američkim Državama, dobili su model koji je sadržao tri faktora: (1) razvoj zajednice, (2) negativan uticaj i (3) kvalitet života. Prvi faktor tumačio je $20,53 \%$ varijanse u stavovima prema turističkom razvoju, drugi 15\% i treći 13,43\%. Studiju koja je takođe uključivala tri faktora sproveli su Latkova i Vogt (Látková \& Vogt, 2012). Dobijeni faktori imenovani su kao: lični benefit 
Milošević, S., Perić, D., Vujinović, M. - Stavovi lokalnog stanovništva prema uticaju turizma na Paliću 2020. Fakultet za sport i turizam, Novi Sad, Tims.Acta 14, 41-51

od turizma, pozitivan uticaj i negativan uticaj. Prvi faktor sadržavo je samo 2 ajtema, drugi - 12, a treći 8 ajtema. Istraživanje koje je sprovedeno u Virdžiniji (SAD) autora Boleja, MekGia, Perdua i Longa (Boley, McGehee, Perdue, \& Long, 2014), sadržalo je čak sedam faktora. Dobijeni faktori nazvani su: psihološko osnaživanje, socijalno osnaživanje, političko osnaživanje, lični ekonomski benefiti od turizma, podrška od turizma, pozitivni uticaj i negativni uticaj.

Instrument koji je formiran za potrebe ovog rada je upitnik koji je nazvan Stavovi lokalnog stanovništva prema uticaju razvoja turizma. Upitnik se sastoji od 4 nezavisne varijable i 18 tvrdnji. U odnosu na 4 hipotetska prediktora posmatrane su varijable.

$\mathrm{Na}$ osnovu dobijenih rezultata uočava se da ne postoji statistički značajna razlika u stavovima ispitanika različitih starosnih grupa. Iz vidljivih rezultata zaključujemo da su dve grupe starijih ispitanika dali veću prosečnu ocenu u odnosu na prvu grupu kojoj su pripadali mlađi ispitanici. Većih razlika u odgovorima nema ni $\mathrm{u}$ istraživanjima koje su sproveli Lankford i Houard (Lankford \& Howard 1994), Kuvan i Akan (Kuvan \& Akan, 2005), Andriotis i Vuan (Andriotis \& Vaughan, 2003). Takođe, ne postoji statistički značajna razlika u iskazima ispitanika različitih obrazovnih nivoa. Najvišu ocenu dali su ispitanici sa višim/strukovnim obrazovanjem, dok su najnižu ocenu dali ispitanici sa doktorskim nivoom obrazovanja. Rezultat dobijen u istraživanjima autora Kuvana i Akana (Kuvan \& Akan, 2005) pokazuje da su ispitanici sa nižim nivoom obrazovanja manje kritični prema potencijalnim negativnim uticajima turizma.

$\mathrm{Na}$ osnovu rezultata prikazanih u Tabeli 5 , jasno je da ne postoji statistički značajna razlika u stavovima oba pola, ali može se primetiti da su ispitanice bile strožije u proceni uticaja turizma na Paliću. Ovakav rezultat navodi na zaključak da na analiziranoj destinaciji oba pola imaju veoma sličan stav, kao i da se ovi nalazi ne razlikuju od ranijih istraživanja u odnosu na polnu strukturu (Lankford \& Howard, 1994; Kuvan \& Akan, 2005; Andriotis \& Vaughan, 2003). Tabela 4, takođe, prikazuje i rezultate prema kojima se zaključuje da ispitanici, kod kojih turizam ima uticaja na zaradu, daju višu prosečnu ocenu, čime se potvrđuje da ekonomska korist od uticaja turizma u velikoj meri utiče na iskaze onih ispitanika koji imaju ekonomski benefit. Indikator koji ukazuje na značaj turizma za nacionalnu ekonomiju predstavlja direktan doprinos zapošljavanja u turizmu što pokazuje istraživanje sprovedeno u jednoj studiji (Janković-Milić,
Jovanović, \& Krstić, 2011) pa tako, jedan od ključnih faktora turističkog razvoja i kompetitivnosti destinacije predstavljaju ljudski resursi (Baum, 2015).

Rezultati prikazani u ovom radu veoma su slični rezultatima koji su dobijeni u ranijim istraživanjima sa sličnim ciljem. Anketirani stanovnici su ukazali na dostupnost turističkih resursa koje treba iskoristiti na pravi način i odabirom prave strategije, kako bi se ostvarili pozitivni uticaji turizma. Visoko ocenjivanje pozitivnih uticaja turizma na Paliću daju podršku daljem razvoju turizma. Takođe, ovi rezultati mogu biti veoma značajni u budućem razvoju turizma na destinaciji Palić.

\section{Zaključak}

Veoma bitan segment u razvoju turizma na destinaciji predstavljaju rezidenti. Od velikog značaja je na koji način turizam utiče na lokalno stanovništvo, kao i kako stanovništvo prihvata razvoj turizma, jer na osnovu toga može se predvideti mogući uspeh nekog turističkog proizvoda. Uključivanjem lokalnog stanovništva u planiranje razvoja turizma, koji će se zasnivati na njihovim prioritetima, biće omogućeno zadovoljstvo lokalnog stanovništva. Takođe, uključivanjem lokalne zajednice u planiranje razvoja turizma stvara se održivi razvoj turizma na datoj destinaciji. Ukoliko rezidenti imaju ekonomske koristi od razvoja turizma njihovi stavovi biće pozitivni, dok se sa druge strane mogu javiti i negativni stavovi, ali uglavnom kod rezidenata koji nemaju nikakve koristi od turizma.

Rezultati ovog istraživanja pokazuju da lokalno stanovništvo destinacije Palić veruje da će turizam u budućnosti imati jednu od vodećih uloga u privrednom razvoju. Takođe, ističu da razvoj turizma treba podsticati jer obezbuđuje mnoge prednosti, kako samoj destinaciji, tako i povećanju životnog standarda.

Ograničenja ovog istraživanja uticala su na krajnje rezultate; primarno ograničenje ogleda seupermanentnim promenama stavova ispitanika, što je veoma česta pojava u istraživanjima koja za cilj imaju analizu stavova rezidenata o uticaju turizma. Na promenljivost stavova rezidenata o turizmu utiče mnoštvo različitih faktora, te je zbog toga veoma važno da ovakva istraživanja imaju svoj kontinuitet kako bi se stavovi rezidenata pratili upoređivali.

Naredna istraživanja trebalo bi da uključe i stavove turista o percepciji, imidžu, zadovoljstvu i iskustvu koje 
Milošević, S., Perić, D., Vujinović, M. - Stavovi lokalnog stanovništva prema uticaju turizma na Paliću 2020. Fakultet za sport i turizam, Novi Sad, Tims.Acta 14, 41-51

je ostvareno na turističkoj destinaciji. U tom smislu, bilo bi poželjno da se u budućnosti obrati veća pažnja kako na teorijski, tako i na praktični doprinos u istraživanjima ovog tipa.

\section{IZJAVA}

Autori su svojim izjavama potvrdili nepostojanje bilo kakvog sukoba interesa.

\section{LITERATURA}

Andereck, K. L., \& Vogt, C. A. (2000). The Relationship between Residents'Attitudes toward Tourism and Tourism Development Options. Journal of Travel Research, 39, 27-36

Andriotis, K., \& Vaughan, R. (2003). Urban Residents' Attitudes toward Tourism Development: The Case of Crete. Journal of Travel Research, 42, 172-185.

Bartlett, M.S. (1954). A note on the multiplyng factors for various chi square approximations. Journal of the Royal Statistical Society, 16 (Series B), 296-298.

Baum, T. (2015). Human resources in tourism: Still waiting for change? Tourism Management, 50, 204-212.

Boley, B. B., McGehee, N., Perdue, R. R., \& Long, P. (2014) Empowerment and resident attitudes toward tourism: Strengthening the theoretical foundation through a Weberian lens. Annals of Tourism Research, 49, 33-50.

Boranić-Živoder, S., Tomljenović, R., \& Čorak, S. (2011). Suradnja interesnih skupina u turističkim destinacijama. In Izazovi upravljanja turizmom (pp. 15-32). Zagreb: Institut za turizam.

Božić, A., \& Milošević, S. (2019). Ekološka odgovornost u hotelijerstvu. Tims. Acta, 13(1), 51-60.

Candela, G., \& Figini, P. (2012). The economics of tourism destinations. Bologna: University of Bologna, Department of Economics.

Cohen, J.W. (1988). Statistical Power Analysis for the Behavioral Sciences. New York: L. Erlbaum Associates, Hillsdale.

Denda, S. (2014). Održivi razvoj parka prirode Palić - želja ili realnost Beograd: Geografski fakultet, Univerzitet u Beogradu.

De Vellis, R.F. (2003). Scale development: Theory and applications (2nd ed.). Thousand Oaks, California: Sage.

Gredičak, T. (2009). Kulturna baština i gospodarski razvitak Republike Hrvatske. Ekonomski pregled, 196-218.

Janković-Milić, V., Jovanović, S., \& Krstić, B. (2011). Human Resources in Tourism as a Factor of its Employment and Competitivness Growth - Comparative Analysis of Serbia and Surrounding Countries. Facta Universitatis, 8(4), 433-445.

Jegdić, V. (2011). Turizam i održivi razvoj. Novi Sad: Fakultet za sport i turizam.

Jovičić, D. (2010). Turizam i životna sredina. Novi Beograd: Ton plus. Kaiser, H. (1970). A second generation Little Jify. Psychometrika, 35, $401-415$.
Kaiser, H. (1974). An index of factorial simplicity. Psychometrika, 39 31-36.

Kattel, R. (1966). The scree test for the number of factors. Multivariate Behavioral Research, 1(2), 245-276.

Kuvan, Y., \& Akan, P. (2005). Residents' attitudes toward general and forest-related impacts of tourism: the case of Belek, Antalya. Tourism Management, 26, 691-706.

Látková, P., \& Vogt, C. A. (2012). Residents' attitudes toward existing and future tourism development in rural communities. Journal of Travel Research, 51(1), 50-67.

Lankford, S., \& Howard, D. (1994). Developing a Tourism Impact Attitude Scale. Annals of Tourism Research, 21, 121-139.

Lee, T. (2013). Influence analysis of community resident support for sustainable tourism development. Tourism Management, 34(C), 37-46.

Long, T., Perdue, R., \& Allen, L. (1990). Rural resident tourism perceptions and attitudes by community level of tourism. Journal of Travel Research, 28(3), 3-9.

Mathieson, A., \& Wall, G. (1990). Tourism economic, physical and social impacts. Harlow: Longman.

Milošević, S. (2016). Uticaj socio-ekonomskih elemenata na vrednovanje turizma kao faktora meke moći. Sremska Kamenica: Fakultet za poslovnu ekonomiju.

Milošević, S. (2017). Analiza objektivnih pokazatelja razvijenost turizma u Crnoj Gori. Tims. Acta, 11(1), 31-43.

Rudan, E. (2012). Uloga lokalnog stanovništva u razvoju turizma destinacije. Tranzicija, 58-67.

Stefanović, V. (2010). Turistički menadžment. Niš: Prirodnomatematički fakultet Niš.

Stefanović, V., \& Gligorijević, Ž. (2010). Ekonomika turizma. Niš: Sven.

Stojanović, V. (2006). Održivi razvoj turizma i životne sredine. Novi Sad: Prirodno-matematički fakultet, Departman za geografiju turizam i hotelijerstvo.

Tabachnick, B.G., \& Fidell, L.S. (2007). Using Multivariate Statistics. Boston: Pearson Education, Boston.

Tepavčević, J., Blešić, I., Bradić, M.,\& Ivkov, M. (2019). Stavovi lokalnog stanovništva prema razvoju turizma u Vrbasu. Tims. Acta, 13(1), 15-25.

Tosun, C. (2000). Limits to community participation in the tourism development process in developing countries. Tourism Management, 21(6), 613-633.

Ubavić, P. (2015). Kreiranje konkurentskog profila Srbije kao turističke destinacije. Kuršumlija: Škola biznisa.

Turistička organizacija grada Subotica. (2019). Preuzeto 17. septembra 2019, sa https://visitsubotica.rs

Wang, Y., Pfister, R. E., \& Morais, D. (2006). Residents' Attitudes toward Tourism Development: A case study of Washington, NC. Northeastern Recreation Research Symposium - Collection of Papers, 411-418.

Watkins, M.W. (2000). Monte Carlo PCA for parallel analysis [computer software]. State College, PA: Ed and Psych Associates.

Woosnam, K. M. (2012). Using Emotional Solidarity to explain residents' attitudes about tourism and tourism development. Journal of Travel Research, 51(3), 315-327. 
Milošević, S., Perić, D., Vujinović, M. - Stavovi lokalnog stanovništva prema uticaju turizma na Paliću 2020. Fakultet za sport i turizam, Novi Sad, Tims.Acta 14, 41-51

Datum prijave: 01.07 .2020

Datum prihvatanja: 20.07.2020.

\section{Kontakt}

Srđan Milošević, Fakultet za sport i turizam,

Novi Sad, Radnička 30a

E-mail: srdjan.milosevic@tims.edu.rs

Dušan Perić, Fakultet za sport i turizam,

Novi Sad, Radnička 30a

E-mail: dusan.peric@tims.edu.rs

Miljana Vujinović,

Feketić, Železnička 47

E-mail: miljanavm@gmail.com 